\title{
Agro-industrial cluster of the region: potential participants and management structure
}

\author{
Elena Volkova ${ }^{1, *}$ \\ ${ }^{1}$ All-Russian Scientific Research Institute of Soybean, Blagoveshchensk, Amur Region, Russia
}

\begin{abstract}
The article presents the results of the research work carried out to identify potential participants in the agro-industrial cluster of the Amur region and designs the management structure of the agro-industrial cluster of the Amur region with the definition of the main blocks that make up the external and internal environment of the cluster. The description of potential cluster participants is given. This includes the core of the cluster, which includes a scientific and educational unit and a production unit consisting of representatives of the community of priority sectors of the cluster. In the structure of the internal environment of the agro-industrial cluster of the Amur region, specialized and infrastructure blocks are identified. The functions of the first block are performed by the specialized structural divisions of the My Business center. The second block is represented by enterprises of technical support, supply of fertilizers, plant protection products, biological products, agricultural organizations for the breeding of farm animals and elite seed farms. The external environment of the cluster is represented by an administrative block consisting of the regional authorities, an auxiliary block consisting of financial institutions, as well as a public block consisting of non-profit organizations that contribute to the popularization and information support of the cluster development. Design management structure and the proposed composition of the relevant units of internal and external environment of the agro-industrial cluster will facilitate the implementation of cluster policy in the Amur region, the achievement of target indicators of the strategy of development of territorial cluster of small and medium entrepreneurship in the agro-industrial complex of the Amur region, approved by the resolution of the government of the Amur region.
\end{abstract}

\section{Introduction}

A cluster is a geographically close group of interconnected companies and related institutions in a particular area, connected by common features and complementarity [1]. Is of great importance for stimulating regional economic growth, improve the competitiveness of rural areas, development of agricultural production and increase farmers income [2].

Many scientists, economists and practitioners consider the cluster to be one of the promising directions for the development of the agri-food sector of the economy [3]. In the Russian

* Corresponding author: VolkovaElAl@rambler.ru 
Federation, in order to create and develop agro-industrial clusters, a Concept for the development of agricultural clusters has been developed, which is based on a system-synergetic approach [4].

The concept of the agro-industrial cluster is presented as a multidimensional system of interrelated forms of organization activities (agricultural enterprises, private farms, peasant (farmer) farms, etc.), combined with the aim of introducing innovative technologies, the challenges of environmental protection, more efficiency in the production cycle [5].

In the Amur Region, as in some other regions of the Russian Federation, work is underway to implement the cluster policy. In this connection, research is relevant in the field of identifying potential participants and the management structure of the agro-industrial cluster in the region.

\section{Materials and methods}

The materials for the study were the works of Russian scientists. The paper uses monographic, analytical and abstract-logical research methods.

\section{Results}

The implementation of the cluster policy of the region is managed by the Government of the Amur Region. The coordinating organization is the Non-profit Organization "Fund for Assistance in Lending to Small and Medium-sized Businesses of the Amur Region", which implements the following set of measures:

- organizing and conducting of the General meeting of members of the cluster, and other joint activities of cluster members;

- provides notification of cluster members on joint activities;

- manages the cluster's document flow;

- interacts with state authorities and local self-government bodies according to the decision of the cluster participants;

- conducts information campaigns in the mass media to highlight the activities of the cluster and the prospects for its development.

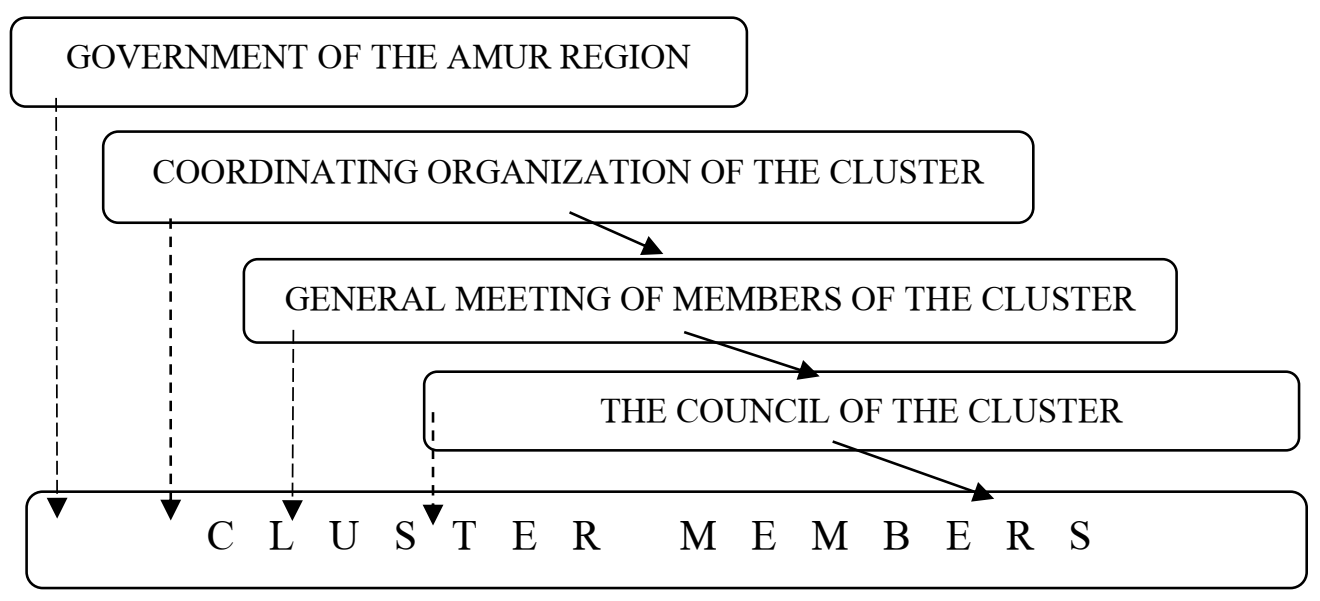

Fig.1. Management structure of the Amur Region agro-industrial cluster. 
The cluster's public management body is the cluster Council, whose purpose is to provide strategic management of the cluster's activities.

The main tasks of the cluster council are:

- determining the key directions of cluster development;

- coordination of the interests of the cluster participants.

To perform tasks, the cluster council has the right to:

- coordinate through the Coordinating Organization and plan the joint activities of the cluster participants, evaluate the results of the cluster activities;

- provide broad public support for the cluster's activities, promote the results of its practical and socially useful activities;

- develop proposals for improving the regulatory framework of the cluster;

- develop a set of measures aimed at improving the operation of the Cluster.

The cluster Council is formed from the number of cluster members. The composition of the Cluster Council is approved at the general meeting of the cluster members by a simple majority of votes, if at least $50 \%$ of the Cluster members are present.

The total number of Cluster Council members cannot exceed 10 people.

The activities of the Cluster Council are carried out in the form of meetings at least 2 times a year. Meetings are valid if they are attended by at least half of its members.

Decisions of the Cluster Council are made by a simple majority of votes of the participants of the Cluster Council meeting.

Members of the Cluster Council carry out their activities on a voluntary basis.

Members of the Cluster Council - individual entrepreneurs take part in the meetings in person. On behalf of the legal entities participating in the cluster, the Cluster Council meetings are attended by the managers in person, or by representatives under the appropriate power of attorney.

The Cluster Council is headed by a Chairman.

The Chairman of the Cluster Council is elected by the members of the Cluster Council by a simple majority of votes.

The Chairman of the Cluster Council shall exercise his / her powers until he / she is reelected at the next meeting of the Cluster Council;

The Chairman of the Cluster Council performs the following activities:

- organizes the work of the Cluster Council;

- specifies the date and topic of the meetings of the Board of the cluster that manages their implementation;

- sign the minutes of meetings of the Board of the cluster.

The head of the Coordinating Organization, or his deputy, acts as the Executive Secretary for the administrative support of the activities of the Cluster Council, keeping the minutes of the meeting of the cluster Council.

To ensure the solution of key issues of cluster development, the Cluster Council has the right to convene a general meeting of cluster participants to form working groups from among the cluster participants and determine the composition of the rights and obligations of the working groups and their participants.

The Cluster Council ceases its activities by decision of the General meeting of the Cluster members. The decision to terminate the activities of the Cluster Council is taken by a simple majority of votes, if at least $50 \%$ of the Cluster members are present.

As a result of the conducted research, potential participants of the Amur Region agroindustrial cluster were identified as part of the classic cluster elements - the cluster core, internal and external environment $[6,7,8]$.

In particular, specialized and infrastructure blocks are being designed in the structure of the internal environment of the agro-industrial cluster of the Amur Region. 
The functions of a specialized block related to the implementation of cluster policy in the region are performed by the structural divisions of the My Business center, created on the basis of the Non-profit Organization "Fund for Assistance in Lending to Small and Mediumsized Businesses of the Amur Region" [9]. Among other structural divisions of this center, the cluster development center has been successfully operating for more than two years [10]. Together with the institutions and organizations that are partners of the center "My Business", the center for cluster development is successfully working on the formation of an agro-industrial cluster in the Amur region [11].

The infrastructure block of the internal environment of the agro-industrial cluster is represented by enterprises of technical support, supply of fertilizers, plant protection products, and biological products. Also, this block includes elite seed farms of the soy-grain direction, seeds of higher reproductions and reproductive seeds; breeding organizations for breeding farm animals of the Amur region. In addition, the supply of breeding cattle is carried out by enterprises of the Krasnoyarsk Territory, the Irkutsk Region and other regions.

The external environment of the cluster is represented by an administrative block consisting of the regional authorities, an auxiliary block consisting of financial institutions, as well as a public block consisting of non-profit organizations that contribute to the popularization and information support of the cluster development.

At the base of the cluster core, it is planned to place a scientific and educational unit that oversees the issues of personnel and scientific support for the implementation of the cluster strategy in the region, as well as a production unit within the community of priority sectors $[6,7,8]$.

First- soy sector, which is represented in the Amur region Soy cluster, which is the interregional investment project, which will allow to establish a sustainable production chain from cultivation of grains and oilseeds through their refining to the production of feed as a basis for the development of livestock meat and dairy. It brings together large enterprises, medium and small businesses to a guaranteed domestic soybean market for processing and exporting finished products.

Integrated processing of soybeans will stimulate the expansion of soybean production, improve the provision of the population with high-grade food, and livestock-high-protein feed, and at the same time create additional jobs and income.

The grain sector, along with soy, is part of the production block of the cluster core and contains production, processing, filling the domestic market with cereals, concentrated feed, contains export potential and interest in the products of the countries of the Asia-Pacific region. Expansion of production is influenced by the quality of the wheat does not meet the requirements of importing countries, the market is hampered by lack of transport and logistics infrastructure, CAS.

The development of the grain sector Cluster involves the expansion of production volumes of export potential of grain and products of its processing on the basis of improvement of soil cultivation, seed selection, development of agro-logistics center for receiving, storage and dispatch of products of grain farming in Russia and for export, guaranteed for small, medium and large businesses wholesale market of wheat forage and food, feed barley, yellow corn, canola, rapeseed oilseed, soybean.

The next sector of the production block of the cluster core is the Potato and Vegetable sector, which involves providing consumers primarily within the region in the autumn-winter period with potatoes and vegetables. Potato production is concentrated in households $90,4 \%$, peasant (farm), individual entrepreneurs and $8.6 \%$, agricultural organizations is 1.0 . Vegetables are placed in households $-82,9 \%$, peasant (farm), individual entrepreneurs $12,2 \%$, agricultural organizations and $4.9 \%$.

The state of the potato and vegetable growing industry is characterized by unprofitable production in the region as a whole. At the same time, the potato yield is $135-149 \mathrm{c} / \mathrm{ha}$. The 
yield capacity of the zoned Lina variety is 213-496 c/ha, Sante - 240-570 c/ha, Adretta-up to $450 \mathrm{c} / \mathrm{ha}$. One of the main reasons for the low yield is the use of depersonalized non-grade seeds.

The sector aims to promote the increase in production of potatoes and vegetables market of high-quality seed varieties, expansion of the wholesale market of potatoes and vegetables food trends with the taste preferences of the customers, product sales premium software for the system of social power and vegetables at below-market prices, the organization of the processing of potatoes and vegetables.

The dairy sector of the agro-industrial cluster is primarily designed to provide the population of the region with dairy products. The level of consumption of milk and dairy products in terms of milk is $52.4 \%$ of the scientifically-based consumption rate.

Despite the emerging trends of increasing milk production, the level of supply of raw materials for processing is $57.0 \%$. There is an insufficient level of utilization of the production capacities of existing processing enterprises. Currently, $68.3 \%$ of milk production is concentrated in private subsidiary farms, $24.8 \%$ in agricultural enterprises and $6.9 \%$ in peasant (farm) farms, individual entrepreneurs. The development of the dairy sector is associated with the increase in production in the public sector and the successful organization of the commodity movement of milk from private subsidiary farms due to the support from the state for the collection and delivery of milk.

The above analysis of the production level indicates a low rate of reproduction of the herd, low productivity of dairy cows.

The development of the dairy sector requires new innovative approaches to herd reproduction, increasing the productivity of dairy cows, taking into account the existing genetic potential of the region, and increasing the marketability of milk.

The meat sector is represented by the production of meat from pigs, poultry, cattle, horse meat, sheep, and rabbits. Taking into account import, including import and export, including export, the level of meat consumption of meat products in the region is $83.6 \%$. The structure of meat production, according to the recommendations of the Ministry of Health of Russia, does not meet the regulatory parameters. The share of cattle meat production is lower by $9.4 \%$, poultry by $3.0 \%$, other animal species by $2.6 \%$, and structural pork production is higher by $13.4 \%$. What determines the increase in the production of meat from cattle, poultry and other animals.

Meat production is carried out by farms and complexes of dairy and meat production, peasant farms, individual entrepreneurs, and personal subsidiary farms. The main production of meat, with the exception of poultry meat, is concentrated in personal subsidiary farms$49.8 \%$, agricultural enterprises- $46.4 \%$ and peasant (farm) farms, individual entrepreneurs $3.8 \%$.

The number of peasant farms and individual entrepreneurs producing cattle meat is 16 , rabbit meat is 2 , and sheep farming is 4 .

The production of cattle and pig meat is generally unprofitable. The main reason is the low productivity of animals, the lack of innovative approaches to ensuring the physiological potential. The lack of coordinated actions in the market ensures the dictate of prices on the part of buyers of raw materials. As a result, the price level does not ensure the cost-effective production of meat.

In the field of production of meat semi-finished products, there are 12 individual entrepreneurs. In the field of processing, added value is formed.

The development of the sector is hindered by the lack of desire of agricultural producers to cooperate, due to a lack of understanding of its effectiveness. The subjects of the cluster, which are united by a single technological process, complement each other and thereby strengthen their own and common competitive advantages. Common economic interests in the creation of an agro-industrial cluster are: 
- increase the volume of production of agricultural products;

- unified pricing policy;

- formation of a unified marketing policy;

- joint innovative technologies and their implementation.

An important aspect of the sector's activities is $t$

Honey sector. Beekeeping of the Amur region is a traditional industry. In 2000, the volume of honey production was more than 1,800 tons, including in agricultural enterprises $8.7 \%$, farms-3.8\%, households- $87.5 \%$. Currently, the volume is reduced to 811 tons. The main production is accounted for by households- $97.2 \%$, farms $-2.4 \%$, agricultural enterprises$0.4 \%$. In the conditions of the region, in addition to honey and wax, you can get $3-5 \mathrm{~kg}$ of parchment, $50 \mathrm{~g}$ of propolis, 300-500 $\mathrm{g}$ of royal jelly, 4-6 $\mathrm{g}$ of bee venom per season from one bee family. Beekeeping is practiced in all districts and urban districts of the Amur region. The leading place belongs to the Arkharinsky district. According to the results of the agricultural census, more than $16 \%$ of bee colonies, the main production and personnel potential, are located here.

The region has developed a multi-channel system of product sales. The volume of buying products from manufacturers at low prices for the purpose of storage and subsequent more profitable sales in cities and large industrial centers has increased. For many owners of apiaries, the problem of sales remains one of the most acute.

Since the demand for honey in the domestic market of Russia is much lower than the demand in international markets, it is necessary to increase the sale of honey for export. It is proposed to achieve this by forming a competitive level of price and quality that meets the needs and requirements of customers of export (international) markets.

To ensure a low cost of production needed to produce honey from the point of view of industrial production, using international experience, technology and expertise, and to build the necessary logistics infrastructure, which will ensure stable and sustainable growth and development production and sales in domestic and international markets on the basis of cooperation and integration in the honey sector.

Sector "non-timber forest products". The Amur region has a great potential of forests for collecting and harvesting non-wood, food forest resources (berries, mushrooms, nuts, birch sap), medicinal plants (leaves, flowers, fruits, buds, roots). But due to the lack of sales markets, the remoteness of the territory from settlements, and high transport costs, these types of forest use are still unclaimed.

The territorial advantage in the potential of forest products is: Zeysky, Selemdzhinsky, Tynda districts;

Arkharinsky district in the reserves of pine nuts, hazel; bracken fern;

Bureysky district - mushrooms, bracken orlyak.

It is in these areas that there is a low and average level of potential for agricultural production, the presence of unemployment among the working-age population. What determines the development of small and medium-sized businesses in this area

\section{Discussion}

The aim of the study was to develop a management structure and identify potential participants of the agro-industrial cluster in the Amur region as part of the main structural blocks of the cluster that ensure the implementation of cluster tasks. 


\section{Conclusions}

Thus, the designed management structure and the proposed composition of the relevant units of internal and external environment of the agro-industrial cluster will facilitate the implementation of cluster policy in the Amur region, the achievement of target indicators of the strategy of development of territorial cluster of small and medium entrepreneurship in the agro-industrial complex of the Amur region, approved by the resolution of the government of the Amur region.

\section{References}

1. M E. Porter, Location, Competition, and Economic Development: Local Clusters in a Global Economy, Economic Development Quarterly, Feb2000, Vol. 14 Issue 1, PP15

2. Ping LIU, Waldemar Koziol, The Experience of International Agricultural Clusters and Enlightens for China, WARSAW 2011. - P. 25. DOI: 10.13140 / 2.1.4268.2889

3. Shchetinina, I.V. Agropromyshlennye klastery i ikh rol' v innovatsionnom razvitii agropromyshlennogo kompleksa Rossii // Innovatsionnaya ehkonomika: ot teorii k praktike: sbornik nauchnykh trudov po materialam Mezhdunarodnoi nauchno-prakticheskoi konferentsii. - 2014. - S. 74-81.

4. Khukhrin A.S., Primak A.A., Pekhutova E.A. Agropromyshlennye klastery: rossiiskaya model' // Ehkonomika sel'skokhozyaistvennykh i pererabatyvayushchikh predpriyatii. 2008. - № 7. - S. 30-34/

5. Perzhu A.A. Vnedrenie agropromyshlennogo klastera v Saratovskoi oblasti // Perspektivnye napravleniya razvitiya ehkonomiki i upravleniya: novyi vzglyad: sbornik materialov II Mezhdunarodnoi nauchno-prakticheskoi konferentsii. - 2018. - S. 46-50.

6. Strategiya (programma) sozdaniya i razvitiya agropromyshlennogo klastera Amurskoi oblasti na period 2019-2023 gg. : otchet o NIR (zaklyuch.) / Dal'nevost. gos. agrar. un-t ; ruk. E. A. Volkova ; ispoln. : A. V. Gorlov [i dr.]. - Blagoveshchensk, 2019. - $100 \mathrm{~s}$. - Bibliogr. : s. 96. - № GR AAAA-B19-219040890002-1.

7. Volkova, E.A. Klasternyi podkhod k razvitiyu i povysheniyu ehffektivnosti otraslei agropromyshlennogo kompleksa regiona / E.A. Volkova // Moskovskii ehkonomicheskii zhurnal: setevoe izdanie. - 2019. - № 12. - S.81. Rezhim dostupa: https://qje.su/ekonomicheskaya-teoriya/moskovskij-ekonomicheskij-zhurnal-12-201967/

8. Volkova, E.A. Klasternyi podkhod v razvitii agropromyshlennogo kompleksa Amurskoi oblasti / Perspektivy razvitiya Rossiiskoi ehkonomiki s tsifrovuyu ehpokhu: mater. II vseross. nauch.-prakt. konf. (Ulan-Udeh, 24 dekabrya 2019 g.) - №3(47). - S.15 -17.

9. Nekommercheskaya organizatsiya «Fond sodeistviya kreditovaniyu sub"ektov malogo i srednego predprinimatel'stva Amurskoi oblastI» [Ehlektronnyi resurs]. - Rezhim dostupa: https://www.amurfondgarant.ru

10. Tsentr klasternogo razvitiya Amurskoi oblasti [Ehlektronnyi resurs]. - Rezhim dostupa: https://amurcluster.ru/

11. Soglashenie o sozdanii agropromyshlennogo klastera Amurskoi oblasti № 2 ot 13.08.2018 g. / Tsentr klasternogo razvitiya Amurskoi oblasti [Ehlektronnyi resurs]. Rezhim dostupa: https://amurcluster.ru/upload/iblock/cb8/Soglashenie-o-sozdaniiAGK.pdf 